\title{
Factors Affecting Customer Adoption to Mobile Banking Service
}

\author{
Dewi Fadila ${ }^{1, *}$, Hendra Sastrawinata ${ }^{2}$, Markoni Badri ${ }^{3}$, Agung Anggoroseto ${ }^{4}$ \\ Mohd. Fadzli bin Ahmad ${ }^{5}$, Tayie Anak Ankus ${ }^{6}$
}

\author{
${ }^{1}$ Business Administration Department. State Polytechnic of Sriwijaya, Indonesia \\ ${ }^{2,3,4}$ Business Administration Department. State Polytechnic of Sriwijaya, Indonesia \\ ${ }^{5,6}$ Commerce Department, Politeknik Mukah Malaysia \\ *Email: dewi.fadila@polsri.ac.id
}

\begin{abstract}
This research aim to determine effect of perceived usefulness, perceived ease of use, perceived of security and trust to customer adoption to mobile banking service. This research involved 100 bank customer that used mobile banking service. This research used Statistical Product Program. The population in this study are the mobile banking user in Palembang. This research sample consist 100 respondents. The result showed that perceived usefulness, perceived ease of use, perceived of security and trust have significant effect to customer adoption to mobile banking service. Partially variable of perceived usefulness, perceived of security and trust have positive effect to customer adoption to mobile banking service, but perceive of ease of use has negative effect. Banks should build customer trust and communicate the usefulness of mobile banking to customer. Banks should increase customer perceive of easy to use by communicate the way to use mobile banking, make the mobile banking appearance simple and easier to use.
\end{abstract}

Keywords: perceive of usefulness, perceived ease of use, perceive of security, trust, customer adoption

\section{INTRODUCTION}

Banking which is included in the financial services sector has a major role in the Indonesian economy. Banking as a business entity in charge of collecting funds from the public in the form of savings and rent back by credit and other forms in order to improve the standard of living of the community.

The rapid development of technology and information currently greatly affects banks in innovating electronic banking products and services. Various technology-based banking services are known as financial technology. Management's ability to adopt new technology will determine the success rate in the development of innovation and services

Adoption of financial technology systems in banking services, including the use of Automated Teller Machines (ATMs), service centre (call centre), internet banking (ebanking), telephone banking, mobile banking (mbanking), video banking, Direct Selling Agents (direct selling agents, DSA) and so on. Banking services are offered to support the smooth collection and distribution of funds, both directly and indirectly related to deposit and credit activities, such as deposit services, payment services, transfer services, billing services, credit and debit services, and others [1]

Financial technology-based banking services commonly used are ATM machines. Almost all banking customers have a debit card to withdraw funds or save at an ATM machine. In line with the next stage of development of financial technology, it is expected that it will become commonplace to use internet banking and mobile banking services [2]

Mobile banking service or commonly abbreviated as m-banking is a service system from bank financial institutions to carry out a number of financial transactions that can be accessed directly by customers through mobile devices such as cell phones. Using mobile banking, customers can access their own accounts such as checking balances, viewing mutation lists, transferring books, making various payments such as electricity, water, credit cards, online shopping, telephone and cell 
phone bills and so on, except those that directly involve cash such as deposits and withdrawals [3]

Various features of mobile banking services are felt to provide benefits in carrying out banking transactions by prioritizing one-handed mobility anywhere and anytime for customers [1] . However, the use of mobile banking technology in various commercial banks shows an uneven comparison, where there are still some banks whose comparison of mobile banking usage is still low [2]. This raises a problem where the growth in the number of customers is not accompanied by the growth of digital banking users, namely internet banking and mobile banking. The financial services industry currently has an increasingly subtle dividing line between banking, financing, insurance, fund management and other industrial sub-sectors that will continue to disappear, so it is very important for banks to find new ways to differentiate themselves [4]

The banking industry, especially mobile banking services, requires efforts to change the paradigm and perspective of customers to realize the benefits offered by mobile banking services, namely helping perform banking transactions by prioritizing one-handed mobility anywhere and anytime. If customers feel the benefits of mobile banking services offered, interest in mobile banking products will also increase [5]. If someone believes that the use of a particular technology will improve the person's work performance. This is called perceived usefulness. Various studies have proven that perceived usefulness has an effect on interest in using mobile banking [1] [2]

Otherwise, the use of technology gave negative impact such is security [6]. Bank customers need confidence that by using mobile banking services, banking transactions are safe and free from risk. Customers need confidence that using mobile banking services can detect and prevent fraud in informationbased systems. If customers feel safe using the service, they will be interested in using banking services.

The goal in marketing services is usually so that service products can be widely accepted and as quickly as possible. Especially in the banking industry, which has a high level of competition, it often demands a fast adoption rate to be able to penetrate the market and immediately build market leadership [7]. Understanding the process of adopting a product will make it easier for banks as financial technology service providers to understand changes in customer behavior and lifestyle. Understanding customer behavior is a strength in providing better customer service which leads to market leadership.

Based on the description above, the problem in this research is how to determine effect of perceived usefulness, perceived ease of use, perceived of security and trust to customer adoption to mobile banking service.

\section{LITERATURE REVIEW}

\subsection{Mobile Banking}

Mobile banking ( $\mathrm{m}$-banking) is a service that allows customers to conduct banking transactions via mobile phones or smart phones. It is one of the electronic banking or internet banking services. Mobile banking services can be used using existing services such as USSD (Unstructured Supplementary Service Data) or through applications that can be downloaded and installed by customers. This mobile banking service is mobile or data is used wherever and whenever desired.

Mobile banking services allow customers to check balances and history of banking transactions, pay for financial transactions from person to person, provide information on the location of the nearest ATM or bank branch office, provide reports and summaries of financial activities according to customer requests, inform financial transaction activities and provide payment services. electronic billing or other multi payments.

\subsection{Perceived of usefulness}

Perceived of usefulness is a person's level of confidence in using a system that will facilitate various jobs so that work can be done more quickly [8] Where the perceived usefulness identify the various benefits or advantages that users receive by using the internet to conduct transactions.

There are importance influence of perceived usefulness consists of the following dimensions: [9]

1) The use of the system can improve individual performance

2) Able to increase the level of productivity

3) Able to increase the effectiveness of individual performance

4) Able to provide benefits for individual users.

In contrast to previous research, provide following dimensions of perceived usefulness: [8]

1) Able to increase productivity

2) Make work faster

3) Support activities

4) Effective

5) Helpful

\subsection{Perceived Ease of Use}

Perception of ease of use is the extent to which a person believes in using a system and feels that he will be free from an attempt to use it [10] Perceived ease of use can be defined as the degree to which a person trusts the use of a particular system and is perceived to reduce the effort or ease someone in doing something [5]

Several dimensions of perceived ease are [11]

1) Individual interaction with the system is clear and easy to understand

2) It doesn't take much effort to interact with the system.

3) Easy to use

4) Easy to operate the system according to what the individual wants to do 


\subsection{Adoption}

The main issue in marketing and consumer behavior is acceptance of a new product or service. Researchers specializing in the deployment of innovations are particularly interested in understanding the deployment process and the adoption process. The adoption process is a micro-process that focuses on the stages that individual users go through when deciding to use or reject a new product [5]

The assumption underlying the adoption process is that users are engaged in an in-depth information search. The adoption process consists of stages of awareness, interest, assessment, trial and use. Although the traditional adoption process looks simple, it is not enough to fully describe the complexity of the process of adopting a product to consumers [5

Adoption of some products and services may have minimal consequences, whereas the adoption of an innovation may lead to major behavioral and lifestyle changes. This study seeks to provide data on whether the use of mobile banking services is a form of adoption of innovations that have a major impact on society

\section{RESEARCH METHODOLOGY}

This research include to causal research that seek relationship above independents and dependent variable. Population of this research are users of mobile banking in Palembang. Sample is a part of population that has same characteristics and represent population. This research involved 84 samples.

Table 1. Validity \& Reliabilty Test collect were normal so that can calculated used of regression analysis.

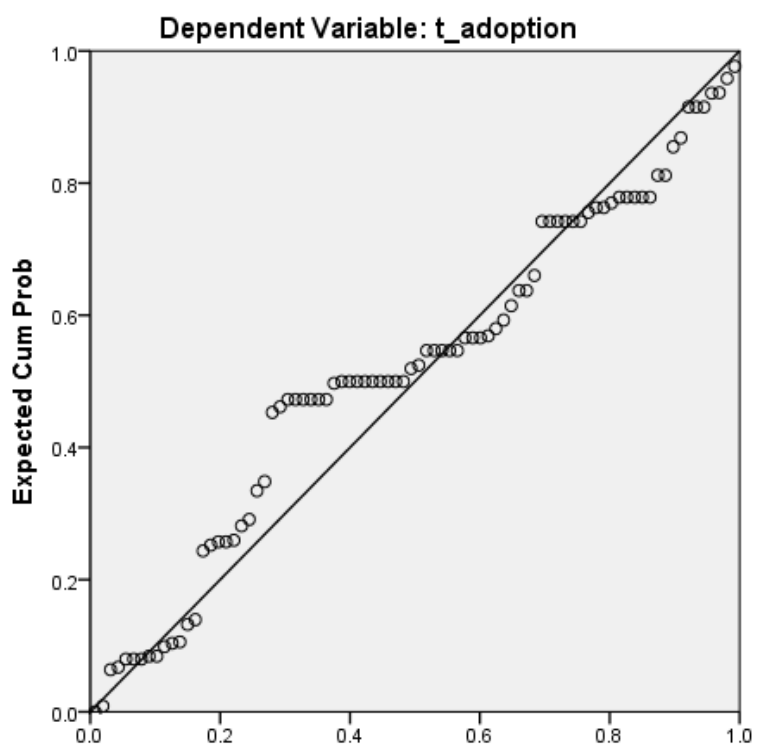

Figure 1. Normality Test

\section{FINDINGS}

Respondents of this research dominant gender is male $(54,7 \%)$. Respondents are consumer of Bank Mandiri (39,5\%), BNI (19,8\%), Other banks (17,4\%). Respondents use mobile banking to transfer, payment of online shopping, monthly expensive payments, etc.

\begin{tabular}{|c|c|c|c|c|c|}
\hline No & Variable & & $\begin{array}{l}\text { Cronbach } \\
\text { alpha }\end{array}$ & Constructs/Indicator & $\begin{array}{l}\text { Corrected Item- } \\
\text { Total Correlatio }\end{array}$ \\
\hline \multirow[t]{3}{*}{1} & \multirow[t]{3}{*}{$\begin{array}{l}\text { Perceive of } \\
\text { Use }\end{array}$} & \multirow[t]{3}{*}{$\mathbf{x 1}$} & \multirow[t]{3}{*}{0,756} & $\begin{array}{l}\text { Mobile banking make more effective } \\
\text { transaction }\end{array}$ & 0,714 \\
\hline & & & & Mobile banking make quicker transaction & 0,705 \\
\hline & & & & $\begin{array}{l}\text { Mobile banking is very suitable for my } \\
\text { financial management }\end{array}$ & 0,382 \\
\hline \multirow[t]{3}{*}{2} & \multirow{3}{*}{$\begin{array}{l}\text { Perceive of } \\
\text { Ease }\end{array}$} & \multirow[t]{3}{*}{$\mathbf{x} 2$} & \multirow[t]{3}{*}{0,690} & Learning mobile banking is easy for me & 0,553 \\
\hline & & & & $\begin{array}{l}\text { Use of mobile banking is easy way for bank } \\
\text { transaction }\end{array}$ & 0,331 \\
\hline & & & & $\begin{array}{l}\text { Mobile banking make financial transaction } \\
\text { more flexible }\end{array}$ & 0,672 \\
\hline \multirow[t]{3}{*}{3} & \multirow{3}{*}{$\begin{array}{l}\text { Perceive of } \\
\text { Safety }\end{array}$} & \multirow[t]{3}{*}{$\times 3$} & \multirow[t]{3}{*}{0,775} & Mobile banking is safety to use & 0,671 \\
\hline & & & & $\begin{array}{l}\text { I'm not worried to gave my personal } \\
\text { information toward mobile banking }\end{array}$ & 0,569 \\
\hline & & & & I'm feel safety to use mobile banking & 0,635 \\
\hline \multirow[t]{3}{*}{4} & \multirow[t]{3}{*}{ Trust } & \multirow[t]{3}{*}{$\mathbf{X} 4$} & \multirow[t]{3}{*}{0,875} & $\begin{array}{l}\text { Mobile banking has trusted quality of banking } \\
\text { service }\end{array}$ & 0,852 \\
\hline & & & & $\begin{array}{l}\text { I believed that mobile banking make banking } \\
\text { operational better }\end{array}$ & 0,852 \\
\hline & & & & $\begin{array}{l}\text { I believed that mobile banking serve customer } \\
\text { satisfaction. }\end{array}$ & 0,608 \\
\hline \multirow[t]{3}{*}{5} & \multirow{3}{*}{$\begin{array}{l}\text { Attitude } \\
\text { toward } \\
\text { Adopting } \\
\text { Mobile } \\
\text { Banking }\end{array}$} & \multirow[t]{3}{*}{$\mathbf{Y}$} & \multirow[t]{3}{*}{0,844} & $\begin{array}{l}\text { Mobile banking is useful service according my } \\
\text { experience }\end{array}$ & 0,836 \\
\hline & & & & $\begin{array}{l}\text { I have positive experience in use of mobile } \\
\text { banking }\end{array}$ & 0,513 \\
\hline & & & & I like mobile banking service & 0,823 \\
\hline
\end{tabular}

The research method used survey method. The survey method is a data collection method based on questions submitted to respondents designed to obtain information from respondents. The data collection procedure used in this study is structured data collection through a questionnaire. The scale that used is 4 points of likert scale. This study uses a statistical program (SPSS). First step to know the reliability test and validity test. The research instrument can be said to be valid if $r$ arithmetic $>r$ table. All the indicator are valid and reliable. The data 


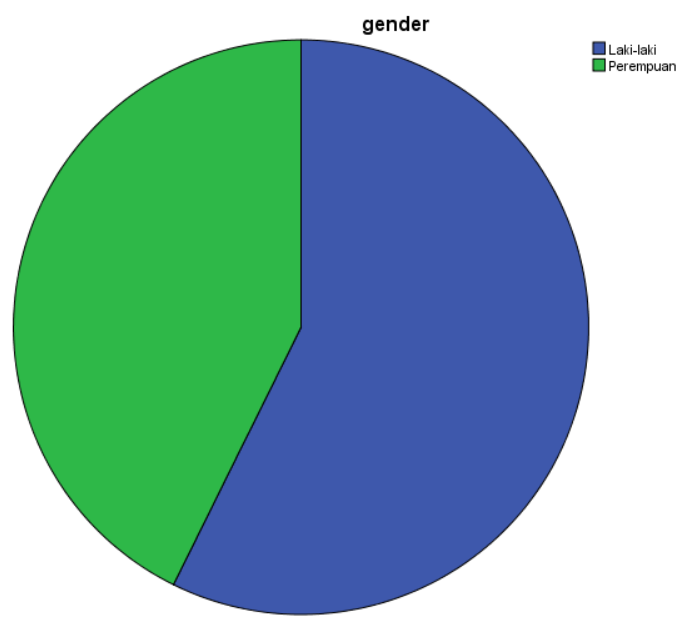

Figure 2. Respondent's Gender

Table 2. Respondent's Name of Bank

\begin{tabular}{|l|l|}
\hline Name of Bank & Percent \\
\hline Bank Mandiri & 39,5 \\
\hline BRI & 9,3 \\
\hline BNI & 19,8 \\
\hline BCA & 5,8 \\
\hline Bank Danamon & 1,2 \\
\hline Others & 17,4 \\
\hline Missing system & 7 \\
\hline & 100 \\
\hline
\end{tabular}

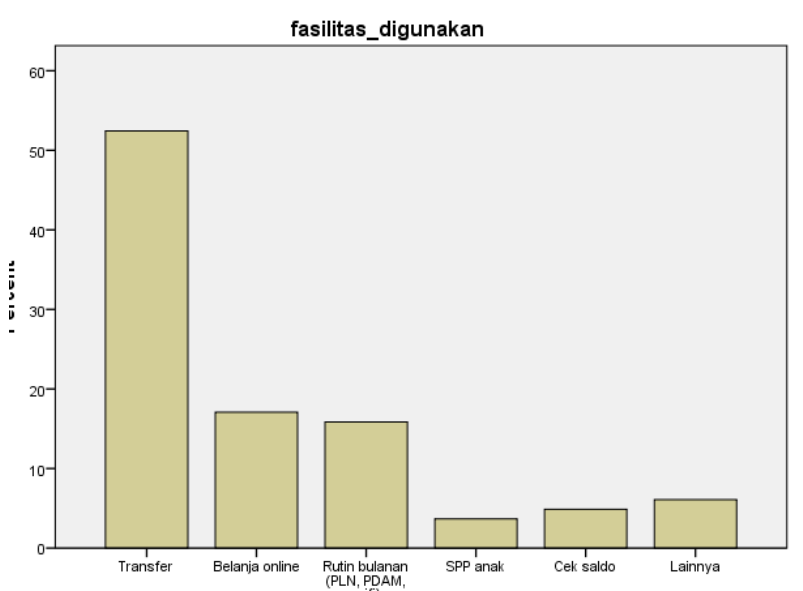

Figure 3. Use of mobile banking

This research finding that perceived usefulness, perceived ease of use, perceived of security and trust has a strong effects to customer adoption to mobile banking service.

Table 3. Model Summary

\begin{tabular}{|l|c|r|c|r|}
\hline Model & $\mathrm{R}$ & $\mathrm{R}$ Square & $\begin{array}{c}\text { Adjusted R } \\
\text { Square }\end{array}$ & $\begin{array}{c}\text { Std. Error of } \\
\text { the Estimate }\end{array}$ \\
\hline 1 & $.881^{\mathrm{a}}$ & .775 & .764 & .69721 \\
\hline
\end{tabular}

Table 4. Coefficients

\begin{tabular}{|c|c|c|c|c|c|c|}
\hline \multirow[b]{2}{*}{ Mod } & & \multicolumn{2}{|c|}{ Unstandardized Coefficients } & \multirow{2}{*}{$\begin{array}{c}\begin{array}{c}\text { Standardized } \\
\text { Coefficients }\end{array} \\
\text { Beta } \\
\end{array}$} & \multirow[b]{2}{*}{$t$} & \multirow[b]{2}{*}{ Sig. } \\
\hline & & B & Std. Error & & & \\
\hline \multirow[t]{5}{*}{1} & (Constant) & .143 & .735 & & .194 & .847 \\
\hline & t_ease & -101 & .103 & -.079 & -.985 & .328 \\
\hline & t_safety & .082 & .072 & .089 & 1.132 & 261 \\
\hline & t_useful & .531 & .092 & 464 & 5.765 & .000 \\
\hline & t_trust & .504 & .096 & .490 & 5.248 & .000 \\
\hline
\end{tabular}

As coefficient table, the regression formula as

$\mathrm{Y}=0,143-0,101$ perceived of ease of use $+0,531$ perceive of useful $+0,082$ perceived of safety $+0,504$ trust.

The result showed that perceived usefulness, perceived of security and trust have significant effect to customer adoption to mobile banking service. The dominant variable that affect customer adoption is perceived of useful. Respondents agree that mobile banking made transaction more effective and quicker. So mobile banking represents customer needs of financial service in banks.

But perceive of ease of use has negative effect. Respondents perceived that mobile banking still complicate and hard to understand. Respondents hope that the appearance of mobile banking more simple and easy to understand.

Banks should build customer trust and communicate the usefulness of mobile banking to customer. Banks should increase customer perceive of easy to use by communicate the way to use mobile banking, make the mobile banking appearance simple and easier to use.

\section{REFERENCES}

[1] Pranoto, Margaretha Oktavia. 2020. Analisis Pengaruh Persepsi Manfaat, Persepsi Kemudahan, dan Keamanan terhadap Minat Nasabah Menggunakan Mobile Banking (Studi Kasus pada PT Bank Rakyat Indonesia (Persero) Tbk Kantor Cabang Semarang Pandanaran). Keunis Majalah Ilmiah. ISSN No 2302-9315. Vol 8 No 1 Thn VIII Januari 2020.

[2] Febrima, Nade. Zulkarnain. 2019. Analisis Persepsi Manfaat dan Kemudahan Penggunaan terhadap Minat dan Adopsi Internet Banking pada PT Bank Rakyat Indonesia (Persero) Tbk, Cabang Pangkalan Kerinci. Jurnal Tepak Manajemen Bisnis. Vol XI. No 2 April 2019

[3] Setiawan, Heri. 2016. Pengaruh Kualitas Layanan, Persepsi Nilai dan Kepercaaan terhadap Kepuasan dan Loyalitas Pengguna Layanan Mobile Banking. Jurnal Keuangan dan Perbankan. Vol 20. No 3 September 2016 
[4] Kotler, Philip. Hermawan Kertajaya. Iwan Setiawan. 2017. Marketing 4,0. Bergerak dari Tradisional ke Digital. Penerbit PT Gramedia Pustaka Utama, Jakarta. Kompas Gramedia.

[5] Davis, F.D. 1989. "Perceived Usefulness, Perceived Ease of Use, and User Acceptance of Information Technology”. MIS Quarterly, Vol.13, No.3

[6] Rahardjo, Budhi. 2016. Keamanan Perangkat Lunak. PT Insan Infonesia

[7] Schiffman, Leon. Kanuck, Leslie. 2010. Consumer Behavior. Prentice Hall.

[8] Lui, Hung Kit dan Jamieson, Rodger. (2003). Integrating Trust and Risk Perceptions in Business to Consumer Electronic Commerce with Technology Acceptance Model. ECIS 2003 Proceedings. Paper 60.

[9] Venkatesh, V., Morris, M.G., Davis, G.B., \& Davis, F.D. (2003).User acceptance of information technology: Toward a unified view. MIS Quarterly, Vol. 27 No. 3, pp. 425-478

[10] Luarn, Pin dan Hsin-Hui Lin. 2005. Toward an Understanding Of The Behavioral Intention to Use Mobile Banking. Elsevier. Journal of Computers in Human Behavior, 21, 873-891

[11] Venkatesh, Viswanath, and Davis, F.D. 2000. A Theoritical Extension of the Technology Acceptance Model: Four Longitudinal Field Studies. Management Science. Vol.46, No.2, Pebruari, pp.186-204 